\title{
The Notion of Divorce among the Muslim Women during Medieval Period and Contemporary Times: A Feminist Perspective
}

\author{
Pirzada Athar Hussain ${ }^{1}$ \\ ${ }^{1}$ Barkatullah University, India \\ Correspondence: Pirzada Athar Hussain, Department of Sociology and Social-Work, Barkatullah University, Bhopal \\ M.P (India)-462026. E-mail: atharsociology@gmail.com
}

Received: February 25, $2014 \quad$ Accepted: April 15, $2014 \quad$ Online Published: April 17, 2014

doi:10.5430/wjss.v1n2p49 URL: http://dx.doi.org/10.5430/wjss.v1n2p49

\begin{abstract}
This paper compares and contrasts the notion of divorce among the Muslims during the medieval period and contemporary times. In this paper some sociological insights and clarifications have been offered. For the medieval period the nature of divorce has been examined in the context of the Arab societies. For the contemporary period the data have been collected from rural and urban areas of the Kashmir valley. In this paper an attempt has been made to examine the nature of divorce particularly from women's point of view and a feminist perspective. The understanding of the societies in medieval and contemporary period and the interpretation offered, suggested that even during the earlier times the Muslim women have not expected their subjugation in the male dominated or patriarchal society. Our understanding of Muslim women highlights the facts that they were able to develop cretin mechanisms which continuously challenged the male dominance. However, in the case of Kashmir valley the Muslim women have challenged the patriarchal system in their own way. Their education and limited new job opportunities have in fact led towards their empowerment. In the case of Medieval Arab societies, especially in the case of the Mamluk societies the women had a sufficient economic base to get divorce, but in the case of Muslim women in Kashmir they have to fallback upon their parental families for the support. It is concluded that the study of medieval Mamluk societies of Arab countries have helped us in the understanding of the problems of divorce among the women of Kashmir. Some interpretations to understand the problems of divorce for the women from the feminist perspectives have also been offered here. The presentation of case-studies also explains the in-depth understanding of the divorced women over there.
\end{abstract}

Kewwords: Divorce, Kashmir, Patriarchal, Mamluk, Muslims, Feminist, Traditionalism, Contemporary position

\section{Introduction}

Divorce among the Muslims has been found it's traditional and religion origin in this universe. Several studies in USA report that the probability of divorce was higher for second than first marriages [Martin and Bumpass 1989, McCarthy 1978, Bumpass and Sweet 1972]. Some other Studies which have been carried out in Bangladesh on the risk of divorce are limited to first marriages or do not distinguish between first, second or more and polygynous marriages [Shaikh et al. 1985, Bhuiya et al. 1999]. The pronouncement of divorce against women was basically an authority of man to imitate if there is not any other option for separation. It was the final step if the conditions between wife and husband were became more troubled. But it doesn't mean that the female's status is inferior in comparison of male, as the female also have an authority to get separation if her husband hesitates to pronounce 'Talaq'1 but a female can utter 'Khula' ${ }^{\text {2 }}$ if the male will accept it then it becomes valid. In the interior portion of this paper we have divided it into five sections like; (i) divorce among the Muslim women: a need for comparisons; (ii) the challenges to patriarchy: a historical review; (iii) some sociological insights: a feminist perspective; (iv) the changing views on divorce in Kashmir valley; and (v) some conclusions are also generated at the last portion of this paper. However, two case-studies have been also mentioned for the overall understandings of this study. These two case-studies also represent the life situations of these divorced women's, as they had challenged the patriarchal dominance and even the second one informs the adverse situation of divorced women over there. It was found in some different studies that the dowry is an agreement between the bride's and the groom's family whereby the bride's family agrees to pay a certain amount of money and/or goods in kind to the groom's family [Aziz and 
Maloney 1985]. Though the practice is illegal under Muslim and state law, it is widespread in Kashmir valley. The practice has consequences for the risk of divorce [Bhuiya et al. 1999]. However, some insights regarding divorce based on feminist perspective has been developed from the history of divorce and status of women in fifteenth century especially among the Mamluk societies has been compared with the status of Muslim women in contemporary period to get its overall understanding. There is evidence that spouses' previous marital disruptions affect the stability of their current remarriage. One study in the USA found that the ratio of divorces per 100 marriages was 16.6 when both partners were in a first marriage and 34.9 when both had been previously divorced once [McCarthy 1978]. Another study reports that homogamous marriages (a single person choosing another single or a divorced person choosing somebody else who is divorced) were more stable than heterogamous marriages [Chamie and Nsuly 1981]. It was also found in the contemporary times and in the medieval times that women's were challenging the system of patriarchal rule over there. Similarly, regarding the feminist perspective, the medieval Islamic societies have given a more status concerning the sympathetic assessment for separated women. In the contemporary periods the empowerment of women has been increasing day-by-day, but still their socio-economic condition was found dependent on males. Moreover, day-by-day the women in valley occupied within their little jobs and the education system have been found influencing the males in a positive way. The people in contemporary times have been found changing their narrow-minded ideology, as they didn't co-operate to utter divorce, but are now trying to compromise with their partners in their own ways. The judgement of judicial courts has been found as per the perspectives of Islamic religion and also trying to convey the people about the adverse and chronic consequences of divorce. Divorce in medieval Middle East societies appears to have been just as common. Due to the general absence of pre-Ottoman court records, the evidence tends to be qualitative rather than quantitative, but several studies based on legal opinions (fatwa's) from medieval North Africa and al-Andalus give the impression of a pattern of frequent and normative divorce. Women's remunerative work, both within and outside marriage, is crucial for understanding the balance of power between husbands and wives, and the phenomenon of frequent divorce. Even if women received lower wages than men, they still gained a substantial degree of economic independence. Wages from work in the textile industry allowed many women, not necessarily elite women, to remain single for long periods of time. Mamluk cities always had a large population of widowed and divorced women, who did not remarry but lived on wages they received for their work as spinners and seamstresses [Youssef Rapoport 2005]. The Qur'an allows divorce on the form of divorce and required the three divorces to be uttered at one month's interval, and to pronounce one divorce at one time, after checking that the woman was not in a state of menstruation. The man could take back his wife before one month will over. If that did not happen and the second pronouncement was made, the man could still back the declarations until the third pronouncement. After pronouncement of the third divorce, the woman could marry another person of her choice. If the second husband divorced her for any lawful reason, and not for making commitment with her divorced husband then the woman was free to remarry her first husband [Engineer, A.A (Ed) (2008)].

\section{Methodology}

In this paper a comparison of some insights has been developed on the basis of literature available concerning the procedure of divorce among the Muslims of medieval Islamic Period and an in-depth look on the contemporary situations of divorce among the Muslims of Kashmir Valley. For the present study an exploratory research design has been utilized to get clear and outstanding understandings concerning the present research problem. The primary data were collected $(\mathrm{n}=300)$ on the bases of an interview schedule. However this paper has been representing the issues regarding divorce on the basis of case-study that approaches the contemporary situations. The comparison is based on the available literature that communicates some insights concerning feminist perspective. It directly explores the contrast pertaining the empowerment of women in medieval Islamic societies and the women of contemporary Islamic society in Kashmir valley India. Some interpretations depict the age-division of divorced respondents and the other one elucidates the areas where these respondents has been found. The numerical representation shows it in the form of its respective percentage and frequency.

\section{Divorce among the Muslim Women: A Need for Comparisons}

The word divorce means break-down the tie of matrimonial contract. In the Islamic law 'Sharia' ${ }^{3}$ there are two kinds of divorce like 'Talaq' is a legal authority especially for male can pronounce against his wife. The second one is 'Khula' particularly for the women to protect herself, if she requires a complete separation from her husband, but it is not valid until her husband approves it. According to the true verses of Holy 'Quran' and traditions of prophet 
Mohammad (R.S.A.W) known as 'Hadeses ${ }^{4}$ God didn't like the utterances of word divorce or 'Talaq' as it is clearly mentioned in both holy books of Islam. In the Holy books of Islam the status of women is equal to man i.e. it has been made lawful for you, that your wives are like a garment for you and you are like a garment for them. Similarly, women who becomes a support in the adverse situations for a male individual during the process of living life. The pronouncement of divorce is authentically allowed in the religion of Islam, but it doesn't mean it should be practiced on the basis of some flimsy grounds. The existence of these single women posed a problem to the patriarchal self-image of Mamluk society, and occasionally there were futile attempts to ban women from the streets of the cities. Mamluk society accommodated these single women by the establishment of exclusively female religious houses, built with the purpose of providing them with their own moral and physical space within the male public sphere. It is the large and unprecedented number of female religious houses established in the Mamluk period that demonstrates how many women managed without husbands [Youssef Rapoport 2005]. Simultaneously, during the origin of Islam people where not giving more preference to women, but after the coming of the Prophet (R.S.A.W) as he announced openly in front of all, that a women should be well cared and also banned the system of murder of females. Moreover, in the mediaeval period of Islam and especially among the Mamluk societies, women had a sufficient economic background, as her family members were providing a special kind of dowry including jewellery, textiles, economic donation and also a part of land was provided by the both sides i.e. from the side of bride it was compulsory and from the side of family members but it was not mandatory [Youssef Rapoport 2005]. The female cloth-peddlers were a familiar sight, and had a crucial role in the distribution of the textile industry's products. They also had privileged access to the private domains of elite households. The divorce was practiced at peak, but a woman didn't suffer economically after divorce. The women was living in a better condition as compared to man, as after the 'fiqa ${ }^{5}$ judgement in the Islamic courts a women was continually getting justice up to the period of military rulers in Mamluk society. Similarly, in the contemporary period we have analyzed some comparisons concerning the situations of Muslim women after divorce in Kashmir valley. It is not only individual decisions on divorce and separation that are clearly affected by the social factors. Divorces are also affected by the nature of their societies. The issue of divorce is especially concerned with the comparison of divorce and separation processes between different European societies and also between different generations [Jaap Drinkers et al 2006]. The status of Muslim women in valley has been found adverse after divorce, as she was not treated as equal as it is stated in the Muslim Mamluk societies. The women after divorce have been found living in destitute. It was revealed during our case-studies as it is also the part of narrative-study, the position of females was representing their astray as they where always in trouble. The women were only considered as a tool for the purpose of house maintenance. The women, who worked in embroidery and sewing, and in particular spinning, could perform these tasks at home. But after the education system, particularly among the new generation the system of female dominance is decreasing day by day. Moreover, the behaviour of women was found challenging in certain cases, as they have offered for divorce and the alteration of behaviour among their parents has also became positive concerning the sufferings of their married daughters. Our study also revealed a lot of information related to male divorcees, as they felt remorse regarding their past mistakes. But there was not any alternative way-out for the re-marriage with their same spouse, as they had made the pronouncement of triple 'Talaq'. However, in the medieval Islamic period at Arabian regions among the Mamluk societies dowry was not only a source of economic sufficiency for a women, but she was also allowed to get share of property from her family members. As it is allowed very authentically in the religion of Islam, but if we compare it among the Muslims of valley there is a lot of difference. A few divorced cases have been analyzed here from Kashmir concerning the same issue, there they were prohibited to do so, as if they go for it the relationships between the women and their brothers had the chances of brake-down. Therefore, Islam allows a female to take her share of property, but in valley people didn't fallow this procedure of their religion. The ulema were Muslim theologians who interpreted Qura'nic verses and the Shari'a. The ulema's position on women was based on the orthodox Islamic tradition symbolized by the notion of women as fitna (potential disorder). Accordingly, women's social interaction with men had to be regulated, which in effect translated into a control over female sexuality, and female seclusion from public space. Like the modernists, the ulema also favoured women's education but only insofar as it centred on religion (i.e. the Qur'an), family values and the moral virtue of women. This was hardly surprising given their view of the Muslim family as being based on sexual hierarchy and the social control of women. Although the ulema elaborated different roles for men and women, these were not based on any inherent distinction between the sexes. In his classic text Beheshti Zewar (Heavenly Ornaments), Maulana Ashraf Ali Thanawi delineated domestic roles for women in great detail, yet acknowledged the equal mental and intellectual potential of men and women. Thanawi was convinced that both girls and boys should receive the same education. [Seema Kazi 1999]. 


\section{The Challenges to Patriarchy ${ }^{6}$ : A Historical Review.}

Women in the mediaeval Islamic period have been found as they had challenged the patriarchal system in their own way [Youssef Rapoport 2005]. There was a lot of respect for them before and after divorce, but also a threat concerning the discrimination of their children after their second marriage. In Mamluk society a women was strong for their economic conditions, as they were not dependent on their husbands. The role of husband was limited

only up to providing food, shelter and clothes for them. The women started Eastern textile industry became richer and they were busy as doing the work of spinners, embroiderers and seamstresses. The dowry was a major factor determining the challenge for patriarchal system, as the Mamluk women were economically independent. Dowries functioned as a form of pre-mortem inheritance ${ }^{7}$ reserved completely for daughters. Once the dowry was donated by the bride's parents, it remained under the woman's exclusive ownership and control throughout marriage, and then again till she becomes widow or divorcee. The welfare state effects cannot be trusted for the divorced women. It was analyzed in some other studies that welfare states arrangements are not sufficient for divorced women. It also discussed about the issues regarding the Income-related arrangements which could reduce the economic strains of divorce and generate employment-related arrangements [Wilfred Uunk 2004]. The women were also having control over them, but there was also a rule of oath regarding divorce originated by the court of Islamic law especially when there was military rule. The patriarchal system was almost defeated over there. The women started agricultural trade, as they had some land given by their parents at the time of marriage. Similarly, the challenging system of patriarchy was also found during the investigation in Kashmir valley, as a number of women offered divorce and they informed that their education helped them to challenge against the patriarchal rule. However, the women in mediaeval Islamic society sometimes also offered for divorce, as if they found themselves dominated by their husbands. According to the history available the husband was forced by the law of order that he had to provide a separate house, day-to-day compensation for his divorced wife. But there was also an especial power in the hands of male individual, as if he found his wife's extra-marital affair then he could call the police for taking action. Moreover, the situation of women was better, but the chances of divorce were more complex over there. Man had also banned the women to visit their neighbours, as sometime she was dominated by the males, but even otherwise the women were in power and challenging the system of patriarchal rule. However, refuted such generalizations, pointing to the differing levels of Western education among Muslims, depending upon their socio-economic status. Large disparities existed in levels of Muslim female education, although these levels of participation were not conspicuously lower than among other Indian women. In the late nineteenth century, only 0.97 per cent of Hindu girls and 0.86 per cent of Muslim girls were attending recognized schools, and no Hindu or Muslim girls had passed the matriculation examination in either Bombay or Madras.39 According to a study in 1901-2, there were 44,695 female secondary students in British India; this represented 27 out of every 100,000 Hindu girls and four out of every 100,000 Muslim girls. Yet, in the United Provinces there were only four Hindu girls attending secondary public school compared to 28 Muslim girls. Enrolment figures for Muslim girls in 1902 placed them ahead of Hindu girls in the provinces of Bombay, Madras and the United Provinces, while they lagged behind in Bengal and Punjab (Fourth Quinquennial Review of Education, India, 1897-1902, Supdt. of Government Printing, Calcutta, 1904, p. 308).

\section{Some Sociological Insights: A Feminist Perspective.}

According to Islamic concerns divorce should not be the first option when any differences between couples come out. Different attitudes and views are natural, and any group - including the family, should learn how to settle its differences peacefully. Feminist was understood as referring to a constellation of social and political concerns, all rooted in the fact of persistent gender inequality. The term feminist was approach for women's studies. it also denotes with women's experiences forming the heart of the discipline, feminist refers more often to an intellectual approach that shares an attention towards female experiences [Elizabeth Kowaleski Wallace 1996]. Islam teaches that marriage should be maintained as long as the essential requirement of a peaceful family life, mutual care and respect have sustainability. The Arabic word "awliya", that is used in the Quran to show the common rights and obligations of women in the society, underlines both the 'responsibility' and the 'authority' that men and women should equally share as undividable members of the society in which all individuals and groups whatever the differences among them may be, have collective responsibility toward the society as a whole. The social role of women requires mixing with men. Islam does not allow any discrimination between men and women, nor does it permit segregation between them as it may be widely understood because of cultural practices or views. What Islam forbids actually is that a man and a woman cannot stay together in privacy, if they are not married to each other or a sexual relation between them is possible. But men and women as individual and groups can meet in public. However, the pronouncement of 
divorce is signifying the lower status of women, as she is always under-pressured by a male whenever she uses to explore her requirements. The history elucidates in-depth information regarding the women's status in the medieval Islamic periods especially among the Mamluk (slave) societies. The 'fatwa' ${ }^{\prime, 9}$ were given by the judges of Islamic courts were always representing a uniform judgement ' $q a d i{ }^{10}$ over there. It is possible to make equal status between two opposite sexes if the seriously urging men and women to join hands as comrades friends and partners in a common struggle to abolish the enslavement of half of humanity [Simone de Beauvoir 1949]. But according to our study, the women in Kashmir valley were found facing a lot of problems and their role of mother was found to be very sensitive and strong, as they were tolerating each and every problem because of their young children. Today a few Muslim women have challenged the male-dominance, but as their socio-economical conditions were not good and they became dependent on their parents or kins-people after their divorce. Personal law (i.e. laws covering family relations, marriage, divorce, inheritance, custody rights, etc.) is a contested arena for the women's movement as well as for Hindu and Muslim conservatives. It not only defines the relationship between men and women in marriage and family relations but also marks the relationship between women and the state. While civil and criminal laws in post-independent India are secular, personal laws are governed by the respective religious laws. Accordingly, Muslim women came under the purview of Muslim personal (family) law [Seema Kazi 1999].

\section{The Changing Views on Divorce in Kashmir}

In 1985, the proposal to nominate the late Prof. Nurul Hasan as Vice-President of India was turned down by Rajiv Gandhi for fear that his atheist beliefs would jeopardize support from the Muslim ulema. In 1986, President Rajiv Gandhi, in deference to the demands of the ulema passed the Muslim Women (Protection of Rights On Divorce) Bill, incorporating provisions of the Shari'a into secular law [Seema Kazi 1999]. According to the contemporary circumstances the position of divorce in Kashmir valley represents its diverse views from the side of judicial statements and other local citizens. It was recently a couple of months before the high-court of Jammu and Kashmir has ruled that a Muslim husband's power to divorce his wife is neither unrestricted nor unqualified. But divorce is the last option to brake-down the matrimonial contract, as the husband has to wait for sometime to solve his problems before the pronouncement of divorce. The gender relations dominate the balance of power and authority within the relationship and raise many of the same issues like, obedience and authority that discusses the relation to Muslim marriage in chapter three [Macfarlane, J. 2012]. The judgement of the court also declared that divorce is the authority of a male person given by Islamic 'Sharia', as it should be utilized on the basis of solid grounds. The 'Talaq' should be pronounced according to the rules and regulations of Islamic 'Sharia'. They also mentioned that the 'Talaq' was utterance in the presence of two witnesses endued with justice, and that 'Talaq' was pronounced during the period of 'Tuhr'11 (in between two menstrual cycles) without making sexual-intercourse with the divorcee during the 'Tuhr'. The male individual has also been required provided maintenance to his wife; the judgement also declared that in the 'Holy Quran' there is no mention of superiority of one gender in the marriage. The massage in chapter 30, verse 21 is not gender specific as it addresses both man and women. 'Allah' says that He created spouses and it is a sign of His mercy. This statement of the 'holy Quran' clears that man and women are equal partners in a marriage. The 'holy Quran' also announces the word 'Zawj ${ }^{12}$ (an Arabic word means a married person regardless of the gender) for both husband and wife (it means a unique pair). Therefore it again makes it clear that husband and wife in Islam are equal and have equal status. However, during our analysis a large number of respondents suggested their diverse explanations regarding the divorce and its consequences. As the mind of the youth is changing through the impact of globalization, a large number of cases were settled again with between them because of the suggestions of their children, parents, kins and acquaintances. The graph A-1 depicts the contemporary and actual level of divorce among the Muslims of Kashmir valley. It also represents the overall understandings concerning the pronouncement of divorce as related or observed by approaching the age-group analysis. The statistical figure also shows the rate of divorce by the following of age-division, as these divorcees has been divided into three categories like; (i) younger, (ii) Middle and (ii) old. However, it shows that the rising rate of divorce was found among the younger generation as compare to Middle and old. Their views regarding the utterance of divorce was negative, as they felt remorse after their past mistakes. The Graph A.2 depicts the overall areas that were found more effected of divorce. It also elucidates the rate of divorce according to the different areas of our research region, as it was one of the main district of Kashmir valley known as district Baramulla. But it was also interpreted that a large majority of individuals in rural and urban areas of valley didn't yet slandered from this process of divorce. A few stated that divorce was an advice for the adverse activities of a person, but today its utilization has became a necessity or fashionable over there. However, among the Mamluk ${ }^{13}$ society divorce was also at peak, but the status of women was equal to man. The prospects of those women who had to live on their own, or chose to do so, were usually not high; 
elite. but at some periods they were at least somewhat better [Youssef Rapoport 2005]. Islam holds that woman is a human being and she has a soul similar to that of man. Thus, men and women were equal to each other in their origin, their abode as well as in their place of return and were as such entitled to similar and equal rights. But, Islam came to India in a particular form, especially with purdah, which is synonymous with high status and respectability. Its enforcement became so pervasive that any woman found without a veil was ruled as shameless and outside of decent society (Upreti, 2000).

Eventually, the present status of women concerning the main thematic assessment depends on the basis of the case-studies. It clearly makes it easy to explain the contemporary position of divorced women for the challenge of patriarchal hegemony in Kashmir valley of India. The case-study explores the socio-economic life participation of these divorcees. It also addresses the focussed issues, as it also known as the reasons for pronouncement of divorce like, extra-marital affair of spouse, level of education, carelessness, improper economic management and dramatic role of kinship etc. As the above mentioned reasons has been found the main steps showing way to reach the point of separation between individuals. On the other hand, as well, a number of divorcees felt in remorse as their utterance of 'triple talaq' divorce was based on some flimsy grounds. They tried to buttress to make some alternative links towards their re-marriage with the same divorced spouse, but the religion of Islam didn't allow re-marrying with same spouse after pronouncement of Triple Talaq method of divorce, as its way out is more complex and complicated in practice. However, the mentioned case-studies elucidates that to some extent the women's are challenging and also their family members made a co-operation to eradicate the ideology among male individuals concerning the discrimination process in the larger society. As well, it is also found that on the other side that some people didn't compromise with these issues, the same category of divorcees was found mostly in villages of district Baramulla of Kashmir valley. In villages mostly people have their conservative ideology towards the impact of globalization concerning the changes as shown in the cities and towns of valley. The $80+$ category of divorcees became more irritable whenever the communication was regarding globalized exposure among their new and young generations.

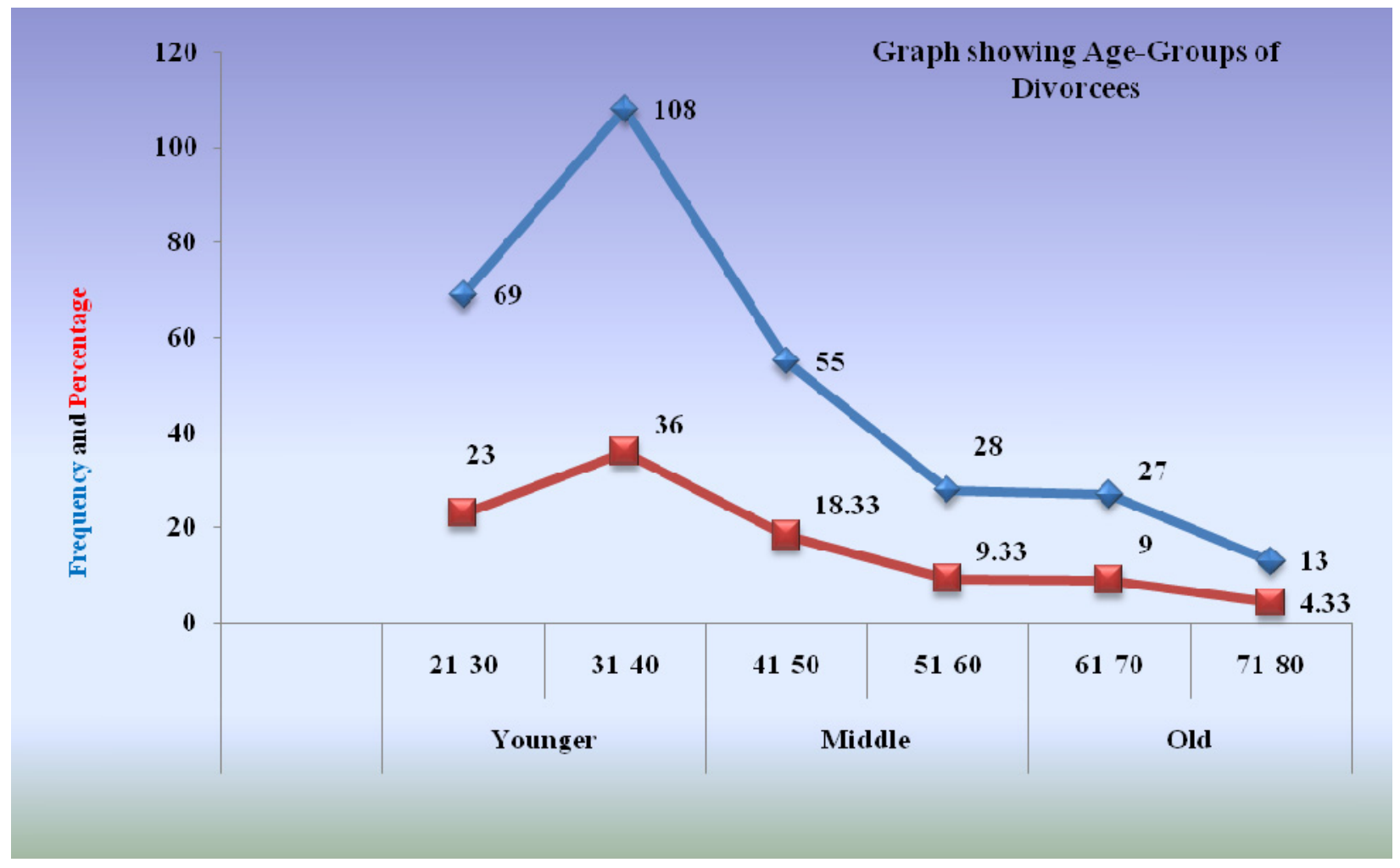

Graph A-1. Depicts the rate of divorce according the age-division of Divorcees 


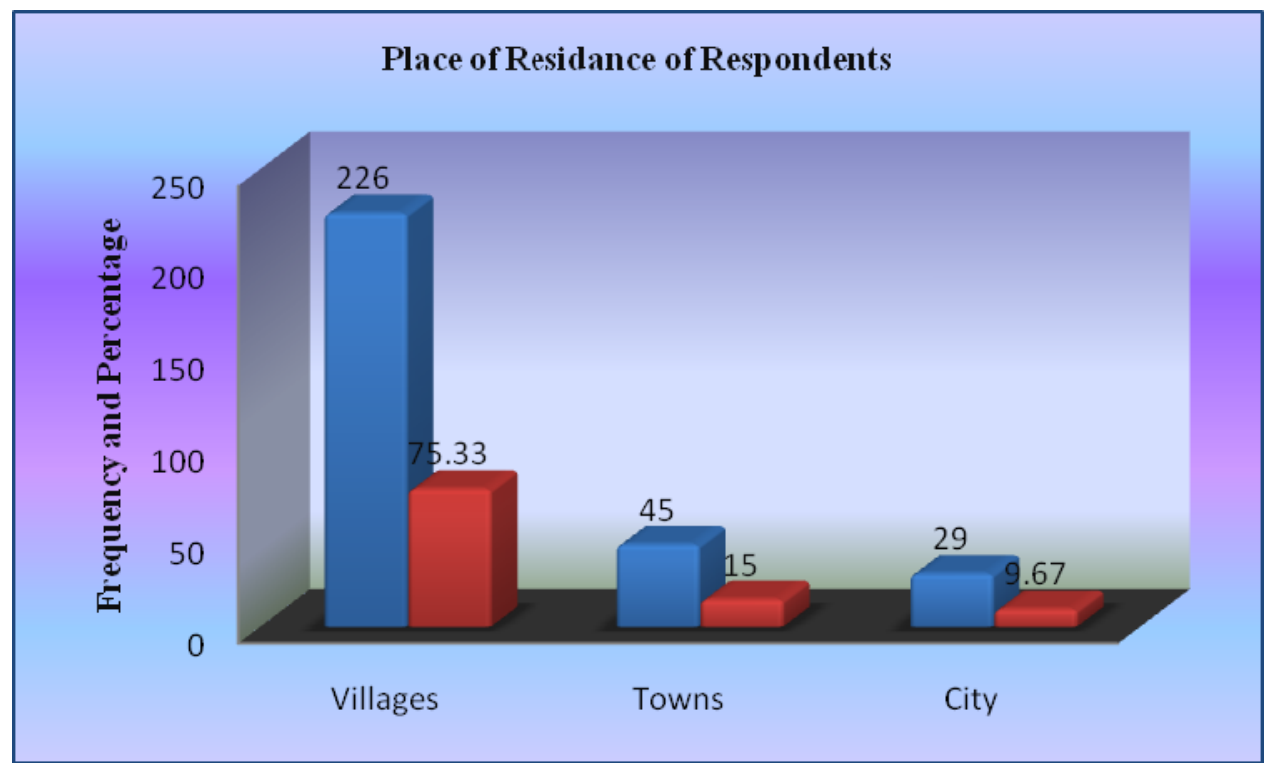

Graph A.2. Depicts the overall effected areas concerning divorce

\section{Some Case-studies and Insights Generated Concerning Patriarchal Challenge and Feminism}

Here we have presented in-depth understandings that were collected with the help of the case-study investigation and it signifies a challenging situation concerning the male dominance and how the women offered for divorce and refused all the suggestions and it also represents that how a male was feeling remorse concerning the pronouncement of divorce. Therefore a number of two case-studies has been presented in this research article; (i) represents that how a women has challenged the patriarchal dominance, as she was well educated that enlightened her inner-consciousness. The second case-study is concerning women who have last her consciousness after divorce. The identification of these respondents has been deliberately not mentioned as it is, as we have promised with them concerning the security of their status. We have mentioned the identification of these respondents as shown by A and B.

\section{Case-Study I}

This case-study concerning ' $\mathrm{A}$ ' is divided into four parts, in the first part the introduction of the respondent is given, in the second part her life situations before the marriage are discussed. In the third part her life situations after the marriage and divorce are given and the fourth part of this study represents some insights are mentioned for the overall understandings. It was analyzed during our case-study that the respondent had faced the pronouncement of divorce before three years. She was presently 42 years old.

\section{Introduction of the Respondent}

The respondent ' $A$ ' is female and recently her family members had tied her second marriage with a shop keeper. She is now happy with her second husband. He provides all facilities and takes care of her. She has presently two children one of her first marriage which was taken by her as Maher from her first husband and the second one is of her present husband. She informed that her first husband's family was very rich, but they did not have any respect for her as she was there like a labour for washing vessels and clothes etc. Though new family is not rich but gives all respect and honor to her. She is presently living with her small family with a good understanding with each other member of the family.

\section{Life Situations before Marriage}

The respondent belonged to a middle class family. Her father was a constructor and they had good economic conditions. She informed that her family members loved her and other three sisters a lot. She is the elder one among them and they have two brothers also. They were living in a joint family where her grandfather and grand mother 
used to take care of them since their childhood. The respondent never faced any kind of problem before her marriage. She has completed graduation and she was pursuing a post graduation course in psychology through IGNOU. After completing her post graduation her family members told her about marriage. She was not willing to marry, as she wished to complete her B.Ed first, but her family members told her that they would only go for her engagement and after completing her B.Ed they would fix the date of marriage. Then after accomplishing her B.Ed family started fixing date of marriage. She was not happy with her marriage because her husband was a doctor and their family was very rich as compared to her own family. Before fixing the date of marriage her father in law demand dowry, she argued with their family members that it is not good and also our religion doesn't allow all these things, but her father told her that, they would give it all for her and her coming offsprings. She was totally unhappy till her marriage day.

\section{Life Situations after Marriage and Divorce}

After marriage the respondent was happy, but not like as she was with her own family. After a few days her mother, father and others went there and suggested her, how to respect her father in-law, mother in-law and her husband. She was happy and was working without any hesitation as if she was in her own family. But even after few months she felt no respect for her husband's family members as were teasing her. However, when she informed her husband that his family was teasing her, her husband refused every request, even when she was pregnant, no one in the family asked her for rest. She was now facing more problems and when it became in-tolerable she told her husband that she was not able to do work under these conditions. Her husband sent her at her parents' family for rest till her delivery. After her delivery in the hospital when she gave birth to a girl child, all the payment was paid by her father. After that her in-laws demanded a car as a gift for her child. But her father and grand father refused her in-laws' demand which ultimately become the reason later for divorce. She was not feeling good after this episode, as she was living with her in-laws. The family members of her husband were always passing comments on her. She informed that her husband was also not behaving well with her father. She was always feeling unhappy over there. After a long time when she was talking on phone with her father and was crying, she narrated whole situation to her father, her father came there and took her with himself at their own home. However, her father was not expecting that her husband would start preparing divorce papers. But when her husband came there, he told her father that now he had no need of his daughter and handed over the divorce papers in her hand. At that time the conditions of the family was very critical. They filed a case in court of law where her husband's family was not ready to compromise, as they gave her alimony and the child was given as Maher to the respondent. Now after the divorce, the respondent was not feeling well and was always sad which compelled her father to go for her second marriage. Though she was not ready to marry again but her grand father and other kins motivated her for second marriage, now she is very happy with her second spouse.

\section{Some Insights}

This case study depicts that the respondent was well educated, which resulted in some thinking about future aspects regarding her life. She informed that how she had tolerated the bad comments concerning her family, as her father had invested a lot of money for dowry. It was also revealed that her education gave her the power as well the confidence when she refused to obey the inappropriate orders of that family. She told us that children of her ex-husband's house were not having any kind of respect for elders. It was also found that after her second marriage her ex-husband came to her new home where he met her second husband and in last movements her ex-husband proposed him that if he will divorce her, he could give him anything. He wished to marry with her as he felt that divorce was a mistake. Her husband asked him to go and informed that he wouldn't like to make any quarrel with him. However, the patriarchal hegemony was found having its main role on the basic structure of this family.

\section{Case-study II}

This case-study concerning ' $\mathrm{B}$ ' is divided into four parts, in the first part the introduction of the respondent is given, in the second part her life situations before the marriage are discussed. In the third part her life situations after the marriage and divorce are given and the fourth part of this study represents some insights are mentioned for the overall understandings. The present case-study has been carried-out from an urban area of our study-field, as the age of respondent was 68 years. She was of the opinion that before five years she had faced the announcement of divorce. 


\section{Introduction of the Respondent}

The respondent ' $\mathrm{B}$ ' is presently living in difficult conditions after her divorce. She was not in a position to tell us information's regarding her life. We consulted her family members for the purpose of the study. In this case it was found that the divorce not only effected the respondent (divorcee) but also effected her family members. Her family members were sad regarding the conditions of respondent, because she was physically disabled and mentally frustrated after her divorce. Her children were very sad concerning the problems of their mother.

\section{Life Situations before Marriage of the Respondent}

It was found that before the marriage of respondent her father had died. Her brothers were always taking care of her and their other family members. They told that she was very innocent and was always helping her family members specially her mother in house hold job. She was not educated, because at that time education was not being considered as important one for women, but they were generally engaged themselves in house hold jobs. Their economic condition was good to some extent as they have a good agriculture land, but their father was only person who was managing it. After her father's death the brothers of respondent started handling their land and other related business. The respondent was their elder sister and they started considering about her marriage. Finally they tied her marriage with a person who was a driver working on the private jobs. They all were happy and at the time of marriage, her brothers provided all facilities which were required for her daily use.

\section{Life Situations After Marriage and Divorce of the Respondent}

The respondent was very happy after her marriage and her in-laws were treating her like their own daughter. Her husband was sometimes misbehaving with her, but she was ignoring it all the times, because she thought that although the job of her husband was not good but he was always caring about him in a very good way. However, the respondent started feeling sad as her husband used to show sympathy for his wife when ever he founded her sad. During the delivery period of respondent, the in-laws didn't let her go to spend the period of delivery in her parent's home, but they suggested her family members that they would take care of her in their own house. When the respondent gave birth to a boy child, at that time they were all very happy and her husband started taking more care of his wife. Their understanding was very strong, but unfortunately after five years of marriage when the respondent was again pregnant, some issues occurred between them. Her husband was almost staying outside at night. She was worried about her husband and was always thinking about his betterment, because she found some drugs from the pocket of her husband's jacket when she was washing clothes. Her family members revealed during our interviews that the respondent informed her brother about it and respondent's brother discussed regarding it with his sister's husband. The husband of respondent couldn't tolerate it and started beating his wife about the concerning matter. The respondent was pregnant when her husband started beating her, she got fainted and then her father in-law admitted her in a nearby hospital, as she was very serious. It was also revealed that her husband had some other bad habits as well, for that purposes respondent was always suggesting her husband to leave these things and were always worried about the future of their children, but her husband was always neglecting these matters. However, when the family members of the respondent were aware about this issue they reached at hospital and were very angry regarding this misbehavior of her husband. The husband of the respondent remained in hiding for some period of time and ultimately when the family members of respondent lodged a case in the court of law, he came there and divorced his wife and also paid some compensation for the children and Maher for his divorced wife. The respondent again gave birth to a boy child, but at that time she was not mentally fit and till now she behaves like a handicapped person.

\section{Some Insights}

In this way it was revealed that the situation of respondent was not well, as the family members of respondent consulted some special doctors for her treatment, but she was not showing any change in her daily life. The family members of respondent also informed that at the time of divorce her husband was not ready to send the child with his wife, but the father in-law of the respondent appealed in front of the court the law that his son was a drug addict person, so he requested to the court not to put the life of child in danger. The respondent was not properly sleeping at the night and was always in despair. The mother of respondent told us that she always pray to God regarding the betterment of her daughter and if not then takes her back from this universe, as she was not in a position to take bath herself. Along with it she had many other physical and mental ailments which became problematic for the entire family. 


\section{Conclusion}

In this way our research concerning the insights that we have developed through the understandings of divorce among the medieval Islamic Mamluk societies has helped us to make the comparisons between contemporary periods and to get in-depth understandings from the point of the feminist perspective. The phenomenon concerning divorce was found as different on the basis of women's empowerment. Similarly, it was also found that the Mamluk-people in the slave society have made sympathetic rules for the women and it was also the procedure of Islamic religion. In medieval Islamic period the rules, regulations and judgements were based upon the fundamentals of Islamic religion. Similarly, it was also found that the status of women was equal to man but the tendency of divorce was growing day-by-dy. After the divorce the females were having strong economic conditions, but after all they were facing a lot of problems concerning their personal life. However, the notion and tendency of divorce in valley was found to be different, as the socio-economic condition of women was adverse if we compare it with the divorcee of Mamluk-society. Only a few women challenged patriarchal system in the valley. The society itself has realized that some issues concerning divorce and separation, as the Quranic views and traditions of Mohammad (R.S.A.W) didn't support for the harassment of female individual and it is stated that their position in this universe is at equal level. Whereas, on the basis of judicial judgement the whole rules and suggestions were also based on the true Islamic law 'Sharia'. As a matter of fact, available literature indicates that there is a close relationship between the spread of female education on the one hand and the development status on the other. As, Safia Iqbal (1986) says in her book (women and Islamic law) that the greatest problems discerned by the Muslim women are that women lack proper knowledge of their faith, and that this is why Muslim men sometimes mistreat their women. (Sharma, 2002). However the contemporary situation of divorce among the Muslims of Kashmir valley is in a very smooth process, as the impact of women's empowerment has challenged the patriarchal dominance.

\section{End Notes}

1. In Islam, 'Talaq' is a form of divorce, but it can only utilized by husband against his wife for complete separation.

2. The Arabic word 'Khula' is a special power for Muslim women, if she requires separation from her husband, but it becomes valid after the acceptance of her husband.

3. The Arabic word 'Sharia' is basically a law of the Islam.

4. The Arabic word 'Hadeses', signifies, the way of life of prophet Mohammad (R.S.A.W), as it was later on presented through some books known as 'Hadeses'.

5. The word 'fiqa' is an Arabic term meaning 'deep understanding' or 'full-comprehension' it also refers to the body of Islamic law extracted from detailed Islamic sources, which are studied in the principles of Islamic jurisprudence. it also signifies concerning the four prominent schools of 'fiqa' within Sunni practice.

6. According to the oxford advanced learner's dictionary, second edition (2002), the meaning of patriarchal as a society, system or country that is ruled or controlled by man.

7. The term inheritance clarifies that among the Mamluk-people the dowries where completely for wife not for her husband, until and unless if she became divorcee.

8. The Arabic word 'awliya' has been found in the true verses of the Holy Quran, so it signifies the equal responsibility and obligations of man and women in society.

9. The fatwa's in Arabic are the legal judgements of Islamic judges and these judgements are mostly irrevocable and are based upon the statements of religion perspectives.

10. The Arabic word 'qadi' signifies the judges in the court of Islamic law.

11. The Arabic term 'Tuhr' explains that three or two menstrual cycles of women

12. The Arabic word 'Zawj' has been found in the holy books of Islamic religion, as it signifies a married person, but regardless of gender.

13. The word 'Mamluk', understands its meaning as a slave, member of the military

\section{Acknowledgement}

Authors are highly thankful to Professor. Arvind Chauhan, Dean, Faculty of Social Sciences Barkatullah University, 
Bhopal M.P (India), for his time to time valuable guidance, support and suggestions. Authors are also thankful to XVII NWISA conference, where this paper was presented.

\section{Declarations}

\section{Conflict of Interest}

Authors declare that they have no declarations of interests to disclose.

\section{Funding}

This research received no specific grant from any funding agency in the public, commercial or not for profit sectors.

\section{References}

Aziz, K. M. A., \& C. Maloney. (1985). Life stages, gender and fertility in Bangladesh, Monograph No 3. Bangladesh. Mohakhali, Dhaka 1212: International Centre for Diarrhoeal Disease Research.

Beauvoir, S. de. (1949). The Second Sex. Vintage books, London.

Bhuiya A., M. Chowdhury, M. Momen, \& Khatun. (1999). Marital disruption in a rural area of Bangladesh: predisposing factors and consequences on women's lives, Scientific Report No. 85. Bangladesh, Dhaka: International Centre for Diarrhoeal Disease Research.

Bumpass, L. L., \& J. A. Sweet. (1972). Differentials in marital stability: 1970. American Sociological Review, 37, 754-766. Retrieved from http://archive.org/stream/selectedcorrelat00vern/selectedcorrelat00vern_djvu.txt

Chamie, J., \& S. Nsuly. (1981). Sex differences in remarriage and spouse selection. Demography, 18, 335-348. Retrieved from http://www.demographic-research.org/Volumes/Vol3/4/html/references.htm

Dronkers, J. et al. (2006). Causes and Consequences of Divorce: Cross-national and Cohort Differences, an Introduction to this Special Issue. Journal of European Sociological Review, No. 22, November, pp. 479-481. Retrieved from http://ff.zcu.cz/kss/veda-vyzkum/pracovni-texty/2013/Variations-in-the-Effect.pdf

Engineer, A. A (Ed). (2008). Rights of women in Islam, Sterling Publishers Pvt. Ltd., New Delhi. Retrieved from $\mathrm{http}: / /$ www.rightlivelihood.org/engineer_publications.html

Kazi S. (1999). Muslim Women in India. Minority Rights Group International. London. Retrieved from http://www.iiav.nl/epublications/1999/muslimwomenindia.pdf

Macfarlane, J. (2012). Islamic Divorce in North America: A Shari'a path in a secular society. Oxford University Press New York, Madison Avenue New York.

Martin, T. C., \& L.L. Bumpass, (1989). Recent trends in marital disruption. Demography, 26, 37-51.

McCarthy, J. (1978). A comparison of the probability of the dissolution of first and second marriages. Demography, $15,345-359$.

Rapoport, Y. (2005). Marriage, Money and Divorce in Medieval Islamic Society. Cambridge University Press, Cambridge New York.

Sarikhani N. (2008). Muslim Women's Work Participation in India', Journal of Social Science, 17(3), 219-222.

Shaikh, K., G. Mostafa, A. Bhuiya et al. (1985). Demographic Surveillance System - Matlab: Vital Events and Migration Tables 1983, Scientific Report No-64. International Centre for Diarrhoeal Disease Research, Bangladesh. Mohakhali, Dhaka 1212.

Sharma, A. (2002). Women in Indian Religions. Oxford University Press, New Delhi.

Upreti, H. C., \& Nandini Upreti. (2000). Women and Problems of Gender Discrimination. Pointer Publishers, India.

UUNK, W. (2004). The Economic Consequences of Divorce for Women in the European Union: The Impact of Welfare State arrangements. The European Journal of Population, 20, 251-285.

Wallace, E. K. (Ed) (2009). Encyclopaedia of Feminist Literary Theory. Routledge Publishers, Routledge, 270 Madison Ave, New-York, NY-10016. 